\title{
Antibacterial Test between Aloe vera and Chlorhexidine Based on the Number of Colony of Streptococcus mutans Atcc 25175 In Vitro
}

\author{
Yetty Herdiyati Nonong ${ }^{1}$, Mieke Hemiawati Satari ${ }^{2}$, Ratna Indriyanti ${ }^{3}$, Selly Patawulandari ${ }^{4}$ \\ ${ }^{1,2,3,4}$ Universitas Padjadjaran, Faculty of Dentistry, Sekeloa Selatan I St, Bandung, West Java, Indonesia 40132
}

\begin{abstract}
Streptococcus mutans is a bacterium which has an important role in the process of dental caries. This bacterium is able to ferment sucrose to glucans that serves as a medium for the initial adhesion of bacteria on the teeth and produces acid that plays a role in the occurrence of dental caries. Aloe vera is an herb that has many health benefits, one of which is an antibacterial effect. Antibacterial Effects of Aloe vera works by inhibiting bacterial metabolism and cause the disruption of the cell membrane permeability so that the growth of Streptococcus mutans can be inhibited. Chlorhexidine is a broad spectrum anti-microbial material with the ability to prevent caries that are widely used in dentistry. The research objective was to analyze the difference in the decrease of number of colonies of Streptococcus mutans between Aloe vera and Chlorhexidine in vitro. The study was conducted using pure experimental research on media containing artificial saliva, cultured Streptococcus mutans ATCC 25 175, $20 \%$ sucrose, then Aloe vera and Chlorhexidine were applied. Paired t-test is used for statistical analysis to analyze the decrease in the number of colonies of Streptococcus mutans in the treatment group and Chlorhexidine Aloe vera. Results of t-test showed that there is a difference in decreasing the number of colonies of Streptococcus mutans significantly between Aloe vera and Chlorhexidine with p-value of $0.0399(\alpha<0.05)$. The research concludes that there is a significant difference in the decrease of the number of colonies of Streptococcus mutans in Aloe vera and Chlorhexidine treatment group in vitro.
\end{abstract}

Keywords: caries, Streptococcus mutans, Aloe vera, chlorhexidine.

\section{Introduction}

Dental caries is the dental hard tissue damage caused by acid products of fermentation of carbohydrate by bacteria. Sucrose fermenting bacteria produce acid. The main bacterium responsible for producing acid and caries is Streptococcus mutans. These bacteria are considered as the most important bacteria in the process of caries. ${ }^{[1],[2]}$

Streptococcus mutans is a bacterium that causes the onset of caries because of the virulence factors that are characteristic of the bacteria. Streptococcus mutans is an anaerobic bacterium that produces lactic acid as part of metabolites and able to adhere to the tooth surface in the presence of sucrose as the substrate. Streptococcus mutans produces lactic acid which can cause salivary $\mathrm{pH}$ decreases to below 5.5 (the critical $\mathrm{pH}$ ). A decrease in the $\mathrm{pH}$ of saliva which repeatedly and continuously can cause demineralization of the tooth surface and eventually dental caries. Demineralization is a state of loss of ions of calcium, phosphate, hydroxyl of the hydroxy apatite crystals, and the solubility of hydroxy apatite that can occur at a $\mathrm{pH}$ below 5.5 (the critical $\mathrm{pH}$ ). ${ }^{[1],[2],[3]}$ High caries prevalence increases the number of colonies of Streptococcus mutans, so caries prevention with antibacterial ingredients to eliminate the growth of Streptococcus mutans is needed. ${ }^{[4]}$

Caries prevention has been studied in various ways one of which uses a chemical that has been done by Miller in 1890 which estimates that an antiseptic to kill bacteria and limit the amount or activity of bacteria. Antibacterial drugs have become part of preventive dentistry since many years ago. Antibacterial agents with broad spectrum can be used to reduce the accumulation of plaque - biofilm or damage the microbial cell. ${ }^{[5]}$
Chlorhexidine is a chemical with broad-spectrum antibacterial activity, which is effective against gram positive and gram negative. Chlorhexidine mouthwash is the gold standard as an antibacterial. Chlorhexidine is highly effective in reducing gingivitis and plaque accumulation. Chlorhexidine is an anti-bacterial agent; the agent is working on the cytoplasmic membrane. Chlorhexidine has a molecule that can bind to the cation anion molecules in bacteria. These interactions can affect bacterial cell membranes, which leads to increased permeability of the bacterial cell wall. Furthermore disrupted cell osmotic balance and lead to leakage component intracellular. ${ }^{[5],[6],[7]}$

The clinical use of chlorhexidine is widely known, but chlorhexidine have side effects if used in the long term. Side effects that occur are brown discoloration on the teeth, tongue, and denture restorative materials, desquamation and pain in the oral mucosa, oral mucosal irritation and dry mouth. Besides, disorders of taste and bitter taste may occur, so poorly received by children anak. ${ }^{[5],[8]}$ Regarding the side effects of chlorhexidine above, herbal alternative materials which do not have these side effect is now being developed. Aloe vera has become the alternative herbal plants. This herb can be used as an antibacterial agent that replace chemicals because it is safe, no side effects and less expensive. ${ }^{[9]}$

Aloe vera contains active substances such as anthraquinone, saponins, acemannan, polysaccharides, salicylic acid, a hormone, tannins, aloin, aloe-emodin, aloetic acids, flavonoids, saponins, sterols, amino acids, enzymes, minerals, and vitamins. Of the active ingredients, there are some that have anti-bacterial effect such as anthraquinone, phenols, acemannan, saponin. ${ }^{[10]}$

Anthraquinone is composed of aloe emodin, aloetic acid, anthranol, chrysophanic acid, cinnamic acid. This 


\section{International Journal of Science and Research (IJSR) \\ ISSN (Online): 2319-7064}

Index Copernicus Value (2013): 6.14 | Impact Factor (2014): 5.611

antibacterial effect works by blocking the action of an enzyme in the biosynthetic process peptidoglycan and lipopolysaccharide/lipotekhoat,damaging the plasma membrane and causes disruption of membrane permeability so that the growth of bacteria can be inhibited. ${ }^{[11],[12]}$ Besides, anthraquinone also have similar properties as soap, which can reduce the surface tension of cytoplasmic membrane of the bacterial cell so that the cell membrane permeability decreases. Saponin contained glycosides have astringent properties of soap as a cleanser and antiseptic. Saponins can dissolve lipids in the cell membrane of bacteria (lipoproteins), thereby decreasing surface tension lipids, and cause bacterial cell function becomes abnormal, lysis and mati. $^{[11],[12]}$

The existence of Aloe vera components such as anthraquinone and saponin can kill bacteria directly, while other components such as acemannan can work as an antibacterial indirectly by stimulating the phagocytosis process leukosit. ${ }^{[13],[14]}$ Aloin, a yellow-colored compound, is a C-glycoside derivative of anthraquinone. Aloin and aloeemodin has strong antibacterial. Aloin and aloe-emodin is the main anthraquinone, which has the polyphenol structure that is capable of inhibiting the protein synthesis of the bacterial cell. Anti-bacterial ability of Aloe vera shows broad spectrum against gram-positive bacteria and gram negatif. ${ }^{[1]}$

\section{Research Method}

The study was conducted at the Laboratory of Chemistry Faculty of Mathematics and Natural Sciences (MIPA), Padjadjaran University in media containing artificial saliva, therein included cultured Streptococcus mutans ATCC 25 175 and 20\% sucrose. Samples were given Chlorhexidine and Aloe vera extracts to see a decrease in the number of colonies of Streptococcus mutans ATCC 25175.

The samples were divided into 6 groups, $\mathrm{CHX}-0$ (Chlorhexidine day 0), CHX-1 (Chlorhexidine day 1), CHX2 (Chlorhexidine day 2), AV-1 (Aloe vera day 0), AV -2 (Aloe vera day-to-1), AV-3 (Aloe vera 2nd day). Examination of the number of colonies of Streptococcus mutans ATCC 25175 done on days 0, 1st, and 2nd after the samples were incubated and treated with antibacterial ingredients. CHX 0 and AV 0 group were incubated after 1 hour ago then the number of colonies were examined. In the group of CHX-1 and AV-1 examination is performed after 1 day of incubation, and after 2 days of incubation in CHX group-2 and AV-2.

Prior to this research, determination of Minimum Inhibitory Concentration on Aloe vera extract and Chlorhexidine has been done. The goal is to determine the smallest concentration of the extract of Aloe vera and Chlorhexidine that still can inhibit the growth of Streptococcus mutans ATCC 25175. Minimum Inhibitory Concentration Test results on Aloe vera extract is $18.75 \%$ and the results of Minimum Inhibitory Concentration on chlorhexidine is at $0.98 \mathrm{ppm}$.

\section{Statistic Test}

Results of the study would be tested using a paired t-test to see equality between Aloe vera and Chlorhexidine based on a decrease in the number of colonies of Streptococcus mutans.

\section{Research Results}

Table 4-1: $S$. mutans colony examination in chlorhexidine (CFU/ml unit)

\begin{tabular}{|c|c|c|c|c|c|c|c|c|c|}
\hline \multirow{3}{*}{$\begin{array}{l}\text { Dilution } \\
\text { concentration }\end{array}$} & \multicolumn{2}{|c|}{ CHX day 0} & \multicolumn{4}{|c|}{ CHX day 1} & \multicolumn{3}{|c|}{ CHX day 2} \\
\hline & \multirow{2}{*}{$\begin{array}{r}\text { Plate } \\
1 \\
\end{array}$} & \multirow{2}{*}{$\begin{array}{c}\text { mean } \\
2\end{array}$} & \multicolumn{3}{|c|}{ Mean plate } & & \multicolumn{3}{|c|}{ Mean plate } \\
\hline & & & & 1 & 2 & & 1 & 2 & \\
\hline $10^{-3}$ & 0 & 0 & 0 & 0 & 0 & 0 & 0 & & 0 \\
\hline $10^{-4}$ & 0 & 0 & 0 & 0 & 0 & 0 & 0 & & \\
\hline $10^{-5}$ & 0 & 0 & 0 & 0 & 0 & 0 & 0 & & 0 \\
\hline $10^{-6}$ & 0 & 0 & 0 & 0 & 0 & 0 & 0 & & \\
\hline & & & & & & & 0 & & 0 \\
\hline & & & & & & & 0 & & 0 \\
\hline & & & & & & & 0 & & \\
\hline
\end{tabular}

Table 4-1 shows the colony inspection CHX ke- day 0 , day 1 CHX and CHX day 2 on the dilution concentration of $10^{-3}$, $10^{-4}, 10^{-5}$, and $10^{-6}$ on the first plate and the second plate, each of which contained as many as $0 \mathrm{CFU} / \mathrm{ml}$ colony with a mean concentration of each dilution of $0 \mathrm{CFU} / \mathrm{ml}$. It showed no growth of Streptococcus mutans in the chlorhexidine from day 0 to day 2 .
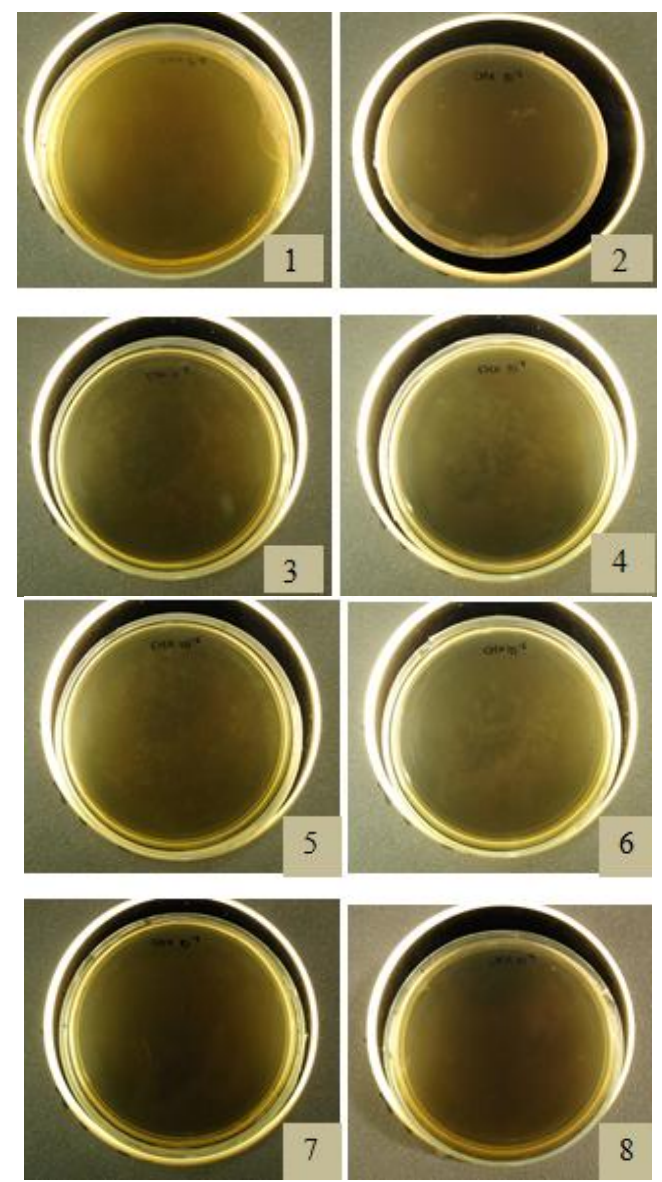

Figure 4.1: Clinical Appearance of Agar Plate of $\mathrm{CHX}$ day 0 


\section{International Journal of Science and Research (IJSR) \\ ISSN (Online): 2319-7064}

Index Copernicus Value (2013): 6.14 | Impact Factor (2014): 5.611
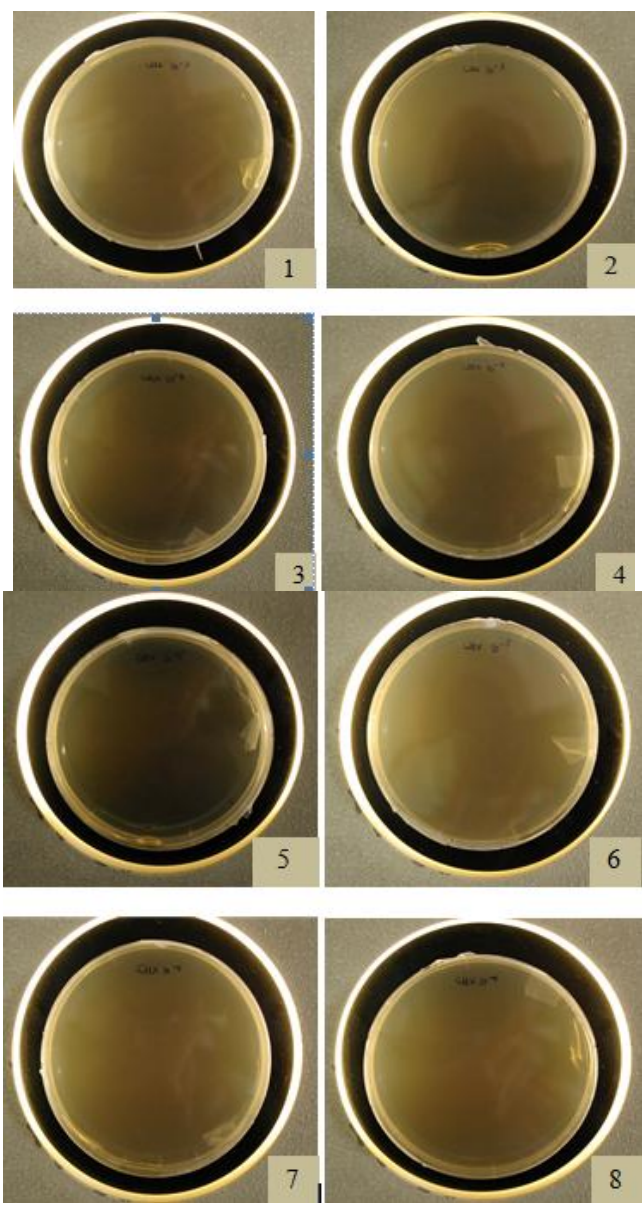

Figure 4.2: Clinical Appearance of Agar Plate of $\mathrm{CHX}$ day 1
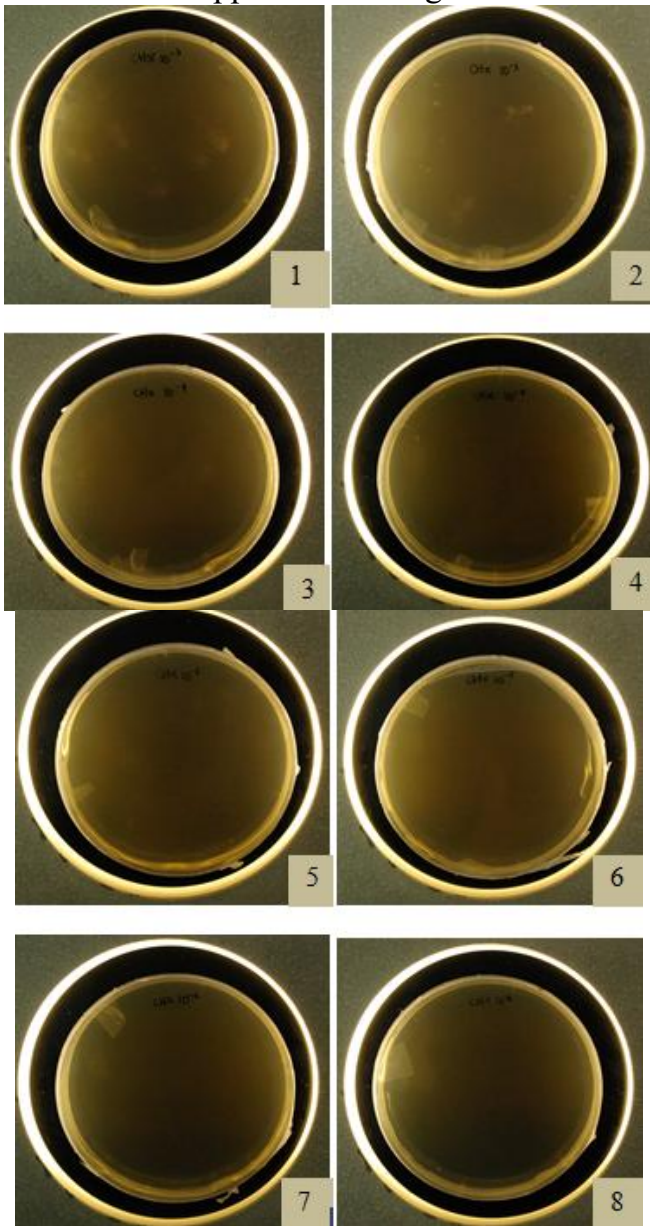

Figure 4.3: Clinical Appearance of Agar Plate of $\mathrm{CHX}$ day 2
Table 4-2: $S$. mutans colony examination in Aloe vera (CFU/ml unit)

\begin{tabular}{|c|c|c|c|c|c|c|c|c|}
\hline \multirow{3}{*}{$\begin{array}{l}\text { Dilution } \\
\text { Concentration }\end{array}$} & \multicolumn{3}{|c|}{ Aloe vera day 0} & \multicolumn{2}{|c|}{ Aloe vera day 1} & \multicolumn{3}{|c|}{ Aloe vera day 2} \\
\hline & \multirow{2}{*}{$\begin{array}{c}\text { Plate } \\
1\end{array}$} & \multirow{2}{*}{\multicolumn{2}{|c|}{$\begin{array}{c}\text { Mean } \\
2\end{array}$}} & \multicolumn{2}{|c|}{ Mean Plate } & & \multicolumn{2}{|c|}{ Mean Plate } \\
\hline & & & & 1 & & & & 2 \\
\hline $10^{-3}$ & 3 & 7 & 5 & 1 & 0 & 0 & 0 & 0 \\
\hline & 18 & 5 & 11,5 & 0,5 & & 0 & 0 & 0 \\
\hline $10^{-4}$ & 1 & 0 & 0,5 & 0 & 0 & 0 & 0 & 0 \\
\hline & 0 & 0 & 0 & 0 & & 0 & 0 & 0 \\
\hline $10^{-5}$ & & & & $0^{0}$ & 0 & & & \\
\hline $10^{-6}$ & & & & $0^{0}$ & 0 & & & \\
\hline
\end{tabular}

Table 4-2 shows the number of colonies Aloe vera examination day 0 , at a concentration of $10^{-3}$ dilution of the colonies are counted $3 \mathrm{CFU} / \mathrm{ml}$ on the first plate and $7 \mathrm{CFU}$ $/ \mathrm{ml}$ in the second plate with the average of $5 \mathrm{CFU} / \mathrm{ml}$. the concentration of $10^{-4}$ dilution of the colonies contained as much as $18 \mathrm{CFU} / \mathrm{ml}$ on the first plate and $5 \mathrm{CFU} / \mathrm{ml}$ in the second plate with a mean of $11.5 \mathrm{CFU} \mathrm{/} \mathrm{ml}$. the concentration of dilution $10^{-5}$, colonies that grow as much as $1 \mathrm{CFU} / \mathrm{ml}$ on the first plate and the second plate shows the colony as much as $0 \mathrm{CFU} / \mathrm{ml}$ with a mean of $0.5 \mathrm{CFU} / \mathrm{ml}$. the concentration dilution of $10^{-6}$ contained colony as much as $0 \mathrm{CFU} / \mathrm{ml}$ on the first plate and the second plate with a mean of $0 \mathrm{CFU} / \mathrm{ml}$.

Aloe vera colony count examination day 1 at a dilution concentration of 10-3 on the first agar plates shows the number of colonies as much as $1 \mathrm{CFU} / \mathrm{ml}$ and in the second plate of $0 \mathrm{CFU} / \mathrm{ml}$ with a mean of $0.5 \mathrm{CFU} / \mathrm{ml}$. dilution concentration of $10^{-3}, 10^{-4}, 10^{-5}$, and $10^{-6}$ in the first and second plates both shows the number of colonies of $0 \mathrm{CFU} /$ $\mathrm{ml}$ with mean dilution concentrations of $0 \mathrm{CFU} / \mathrm{ml}$. Aloe vera colony count examination day 2 on the dilution concentration of $10^{-3}, 10^{-4}, 10^{-5}$, and $10^{-6}$ on the first and second plate both shows the number of colonies of $0 \mathrm{CFU} /$ $\mathrm{ml}$ with mean dilution concentration of $0 \mathrm{CFU} / \mathrm{ml}$.

Aloe vera extracts showed growth of Streptococcus mutans colonies ranging from day 0 to day 1 , while on day 2 showed no colony growth of Streptococcus mutans. 
International Journal of Science and Research (IJSR)

ISSN (Online): 2319-7064

Index Copernicus Value (2013): 6.14 | Impact Factor (2014): 5.611
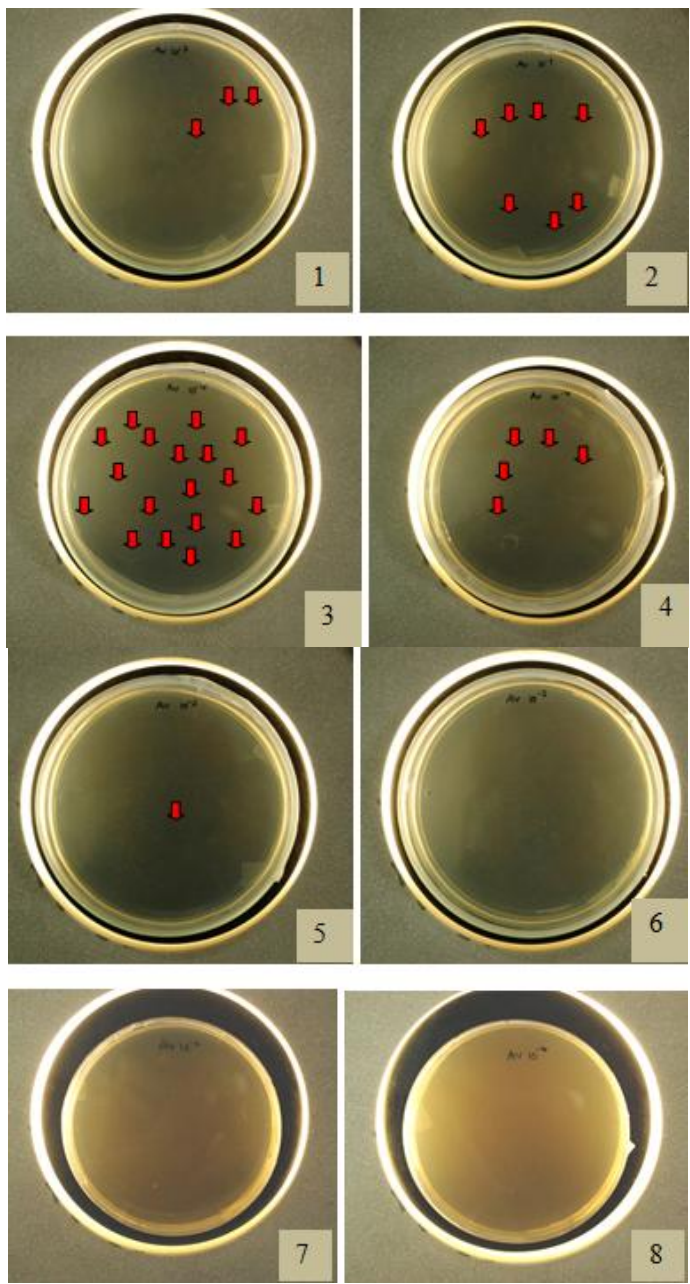

Figure 4.4 Clinical Appearance of Agar Plate of Aloe vera treatment day 0 (The arrows indicate the growth of Streptococcus mutans colonies)
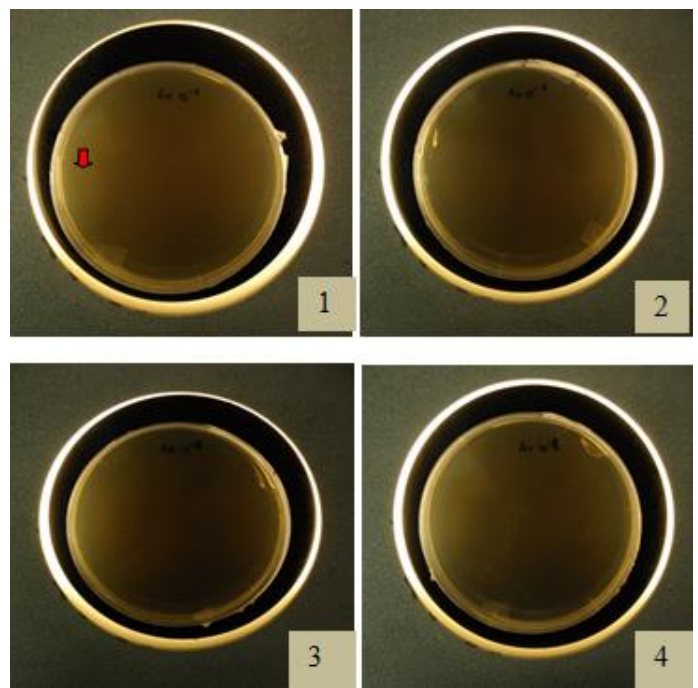
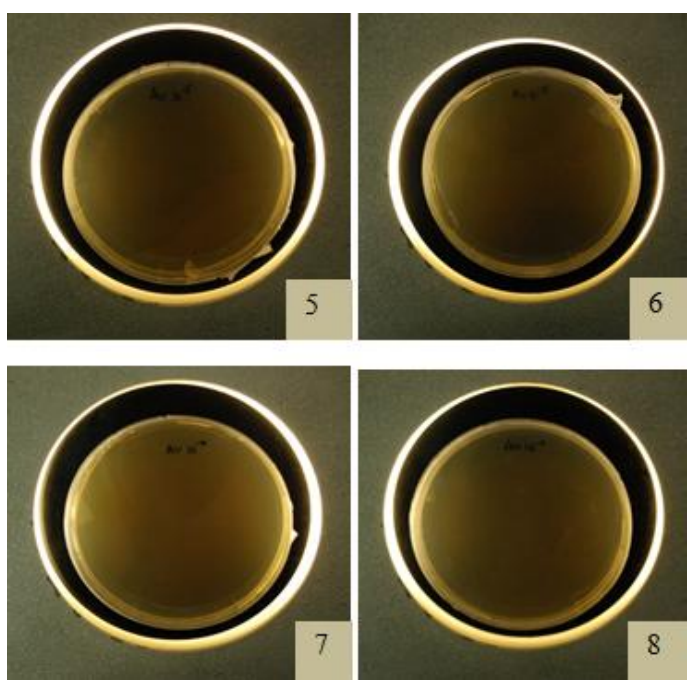

Figure 4.5 Clinical Appearance of Agar Plate of Aloe
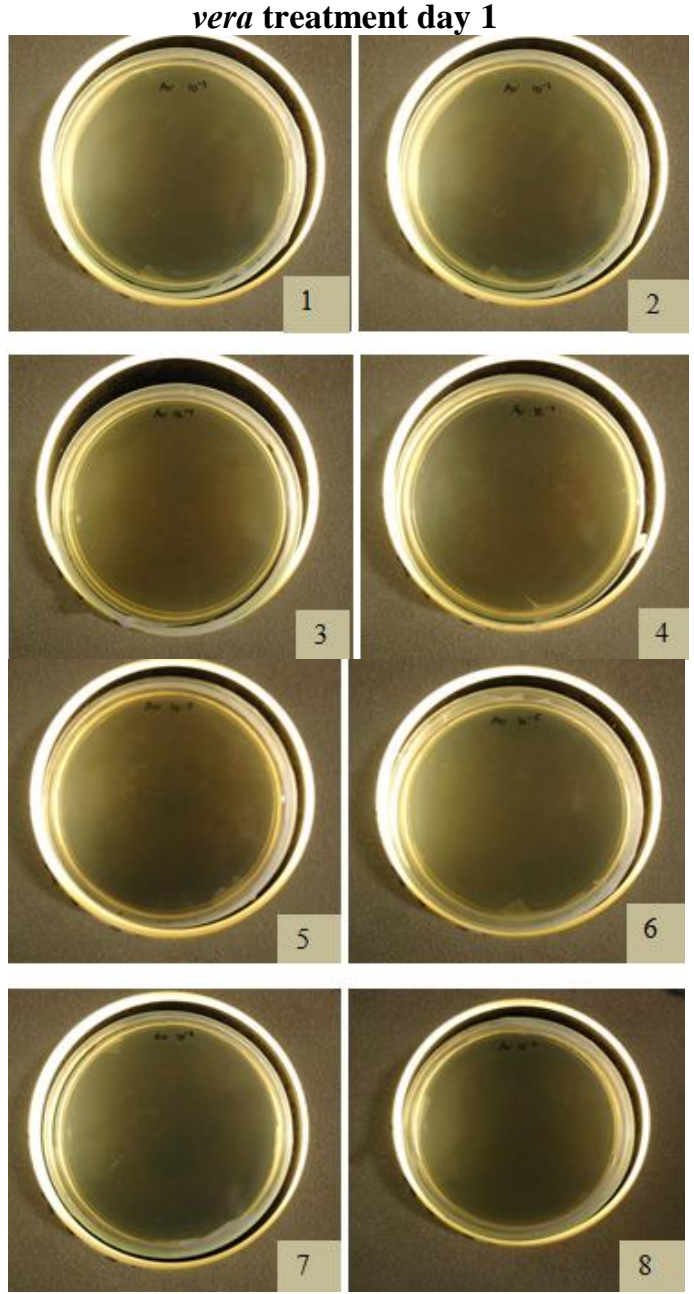

Figure 4.6 Clinical Appearance of Agar Plate of Aloe vera treatment day 2

\subsection{Statistic Test Results}

$\mathrm{T}$ test is used for statistical testing to find equality of two mean at the two populations to determine the difference in decreasing of the number of Streptococcus mutans colonies after Aloe vera and chlorhexidine treatment $\alpha<0,05$. 


\section{International Journal of Science and Research (IJSR) \\ ISSN (Online): 2319-7064}

Index Copernicus Value (2013): 6.14 | Impact Factor (2014): 5.611

Table 4-3: T-Test Statistical Testing Analysis To Determine The Differences Of The Decreased Of Streptococcus mutans Total Colony After Aloe vera And Chlorhexidine Treatment

\begin{tabular}{|l|c|c|c|c|c|}
\hline & \multicolumn{3}{|c|}{$\mathrm{p}_{\text {value }}$} & \multirow{2}{*}{$\begin{array}{c}\text { Value } \\
\mathrm{t}_{\text {count }}\end{array}$} & Meaning \\
\hline CHX0 & 0,399 & & & 1,89 & Significant \\
\hline CHX1 & & 0,0352 & & 1,96 & Significant \\
\hline CHX2 & & & 0,1671 & 1 & Non Significant \\
\hline
\end{tabular}

Note: CHX0 : Chlorhexidine day 0, CHX 1 : Chlorhexidine day 1 , CHX 2 : Chlorhexidine day 2, AV0 : Aloe vera day 0 , AV1: Aloe vera day 1, AV2 : Aloe vera day 2.

In the statistical testing by t-test, a significant difference is seen between the Aloe vera day 0 group and Chlorhexidine day 0 group with $\mathrm{p}_{\text {value }}$ of 0.0399 and $\mathrm{t}_{\text {count }}$ of 1.89 . In the Aloe vera day 1 group and Chlorhexidine day 1 group, a significant difference is seen with $\mathrm{p}_{\text {value }}$ of 0.0352 and $\mathrm{t}_{\text {count }}$ of1.96. In the Aloe vera day 2 group and chlorhexidine day 2 , a significant difference is seen with $p_{\text {value }}$ of 0.1671 and $\mathrm{t}_{\text {count }}$ of 1 .

Conclusion: There is a significant difference at the reduction of the number of Streptococcus mutans colonies on the Aloe vera and Chlorhexidine application.

\section{Discussion}

Streptococcus mutans is a bacterium which has an important role in the process of dental caries. This bacterium is able to ferment sucrose to glucans that serves as a medium for the initial adhesion of bacteria on the teeth and produces acid that plays a role in the occurrence of dental caries. The acid environment in the oral cavity is triggered by Streptococcus mutans to metabolize sucrose. Streptococcus mutans produces acids such as lactic acid as an end result the metabolism of Streptococcus mutans with sucrose as the substrate. Besides being able to produce acid, the bacteria are also able to survive in acidic or low $\mathrm{pH}$ (asiduric) environment. These bacteria are also more asidogenic than other Streptococcus species. Therefore, Streptococcus mutans is a key target in the efforts to prevent dental caries. ${ }^{[15]}$

Streptococcus mutans forms extracellular polysaccharides from sucrose, which is glucosyltransferase (GTF). Glucosyltransferase (GTF) enzyme breaks down sucrose into glucan. Glucan serves as a initial attachment medium of bacteria to the tooth surface and facilitates the accumulation of bacteria. Glucan adhesion on the surface of bacteria is caused by the existence of another protein known as glucan binding protein (GBP). This glucan attachment results in properties of adhesive and cohesive of the plaque on the tooth surface. ${ }^{[16]}$

This study was conducted to see a decrease in the number of colonies of Streptococcus mutans between Aloe vera with Chlorhexidine in vitro. The Media is conditioned in anaerobic atmosphere at a temperature of $37^{\circ} \mathrm{C}$, because the temperature of $37^{\circ} \mathrm{C}$ is the optimum temperature for growth of colonies of Streptococcus mutans. The research uses sucrose at $20 \%$ both on the agar plates and the media, the goal Streptococcus mutans could grow well and produce more glucan so the colony size is big enough to facilitate the colony counting process.

Chlorhexidine group showed no growth of colonies ranging from days 0,1 , until day $2(0 \mathrm{CFU} / \mathrm{ml})$. This is caused by chlorhexidine mechanism that can work progressively on the cytoplasmic membrane. Chlorhexidine has a cationic molecules that can bind groups of negatively charged bacteria (containing sulfa and phosphate). This molecular interactions causes chlorhexidine to be attracted to the charged anion bacterial cell wall through a spesific and strong adsorption (compound of phosphate). chlorhexidine goes into the cytoplasm, cell membrane integrity progressively destroyed, then the permeability of bacterial cell wall is increased. Furthermore cell osmotic balance is disrupted. chlorhexidine binds to phospholipids and causes damage to the cell molecular weight (potassium ion). Furthermore cytoplasm experiences coagulation and precipitation in the cytoplasm of the phosphate groups (ATP and nucleic acids), and finally there is leakage of intracellular components, lysis and death. ${ }^{[5]}$ In addition, chlorhexidine can inhibit glucosyltransferase enzymes that are essential for microbial accumulation on tooth surfaces. [5].[17]

Chlorhexidine is a chemical with a broad spectrum of antibacterial power, highly effective against gram-positive bacteria. Chlorhexidine is used as the gold standard because of its superiority compared to other mouthwash. Superior effect is mainly ascribed to the chlorhexidine high substantivity ability. chlorhexidine can penetrate the plaque biofilm thus killing bacterial pathogens contained in biofilms. Chlorhexidine can also bind tightly to the structure of the teeth, dental plaque, and oral tissues. ${ }^{[5],[6]}$ research conducted by Lakade et al showed a greater decrease in the number of colonies of Streptococcus mutans in chlorhexidine than the combined application of mouthwash containing $0.03 \%$ triclosan, $0.05 \% 5 \%$ sodium fluoride and xylitol. chlorhexidine works by damaging the cell walls of microorganisms that cause them to leak intracellular component.4 previous study proved consistent with the results of this study, colonies did not grow at all (0 CFU / $\mathrm{ml}$ ) on day 0 to day 2 either in the dilution of $10^{-3}$ to $10^{-6}$. Statistically, no significant difference is in seen a decrease in the number of colonies of Streptococcus mutans on chlorhexidine ranging from day 0 to day 2 . It is proved that chlorhexidine has a superior antibacterial effect in reducing the number of colonies of Streptococcus mutans.

Aloe vera showed relatively more colony growth in comparison to chlorhexidine, but Aloe vera showed a good decrease in the number of colonies starting from day 0 to day 2. colonies grew on day 0 at dilutions of $10^{-3}$ with a mean 5 $\mathrm{CFU} / \mathrm{ml}$, with a dilution concentration of $10^{-4}$ and mean of 11.5 CFU / ml, a dilution concentration of 10-5 and mean of $0.5 \mathrm{CFU} / \mathrm{ml}$, and the dilution concentration $10^{-6}$ with a mean of $0 \mathrm{CFU} / \mathrm{ml}$. Colonies grew on day 1 only in dilution $10^{-3}$ with a mean of $0.5 \mathrm{CFU} / \mathrm{ml}$, it is clear that the number of bacterial colonies decreased considerably from day 0 to day 1. Day 2 showed a quite effective decreased in the absence of colonies that grow. Aloe vera extract is proven to inhibit the number of colonies of Streptococcus mutans on the concentration of $18.75 \%$ within 0 days, 1 and 2 days. 


\section{International Journal of Science and Research (IJSR) \\ ISSN (Online): 2319-7064}

Index Copernicus Value (2013): 6.14 | Impact Factor (2014): 5.611

This proves that Aloe vera is able to decrease the number of colonies of Streptococcus mutans, although in this study the antibacterial effect Aloe vera is not as good as chlorhexidine. Statistically, a significant decrease is shown in the group of Aloe vera in reducing the number of colonies of Streptococcus mutans. Aloe vera as an anti-bacterial cannot be equal in reducing the number of colonies of Streptococcus mutans.

Aloe vera is an herbal ingredient that has many benefits for human health and readily available in the environment. Aloe vera contains many active substance components comprising anthraquinone, phenols, acemannan, and saponins are known to have antibacterial properties. This antibacterial effect works by blocking the action of an enzyme in the biosynthetic process peptidoglycan and lipopolysaccharide/lipotekhoat, damaging the plasma membrane and disrupting membrane permeability so that bacterial growth is inhibited. Anthraquinone and saponin has an antibacterial effect which can kill bacteria directly, whereas other components, acemannan, may work as an antibacterial indirectly by stimulating phagocytosis of leukocytes. Saponin as an antiseptic can dissolve lipids in the cell membrane of bacteria (lipoprotein), interfere with the function of bacterial cells and damage the cell membrane of bacteria, lysis and die. ${ }^{[12],[18]}$

Mechanisms of phenolic compounds contained in Aloe vera can cause inhibition of bacteria. Phenol compounds denature the protein and increase the permeability of microorganisms. The interaction between microorganisms produce changes in the charge balance of protein molecules, resulting in changes in the structure of the protein and causes coagulation. Proteins that undergo denaturation and coagulation will lose the physiological activity that it cannot function properly. Changes in the structure of proteins in the cell wall of bacteria will increase the permeability of the cell so that the cell growth is inhibited, then the cells become damaged, causing lysis of bacterial cells. Aloe vera in low concentrations can damage the cytoplasmic membrane, causing leakage of the cell wall, so that the growth of bacteria will be inhibited. ${ }^{[11]}$ The mechanism of action of Aloe vera works by damaging the cell membrane of bacteria gradually, not as progressive as chlorhexidine.

Results of research on both the antimicrobial material exhibited antibacterial effect which can reduce the number of colonies of Streptococcus mutans. When compared statistically, the ability of both anti-microbial materials is not equivalent to lowering the number of colonies of Streptococcus mutans in vitro. This is evident from the results of different colonies in the group of Aloe vera and chlorhexidine group. Chlorhexidine is proven as a better anti-bacterial material and superior than the Aloe vera. Aloe vera is proven not having the capacity that is equivalent to chlorhexidine in terms of reducing colonies of Streptococcus mutans, but Aloe vera can be used as an alternative option of anti-bacterial ingredient in reducing the number of colonies of bacteria Streptococcus mutans, although not as good as chlorhexidine. In addition, chlorhexidine as chemicals if used in the long run frequently is reported to cause side effects and have a bitter taste so poorly received by children. Thus, Aloe vera can be used as an alternative anti-bacterial for its safety, no side effects, improving the taste and the cheaper/more affordable.

\section{Conclusion}

Based on these results it can be concluded that there is a significant difference in reduction of the number of colonies of Streptococcus mutans which were treated by Aloe vera and Chlorhexidine. In other words, anti-bacterial capabilities of Aloe vera cannot be equivalent to Chlorhexidine but when seen from the pattern of decline in the number of colonies of Streptococcus mutans, it could be an alternative as an antibacterial material for the prevention of caries.

\section{References}

[1] Karpinski TM, Szkaradkiewicz AK. Microbiology of dental caries. Journal of Biology and Earth Sciences. 2013.3:1

[2] Henley SCJ, Botha FS, Lall N. The use of plants against oral pathogens. Microbial pathogens and strategies for combating them : science, technology and education. 2013. 1375-1384

[3] Kidd, Edwina. A.M. et al. 2005. Essential of Dental Caries. 3rd ed. Oxford University Press Co. New York. 1-36.

[4] Lakade LS, Shah P, Shirol D. Comparison of anti microbial efficacy of chlorhexidine and combination mouth rinse in reducing the Mutans streptocoocus count in plaque. Journal of Indian Society of Pedodontics and Preventive Dentistry. 2014. 91-96

[5] Scheie AA, Petersen FC. Antimicrobials in caries control. Dalam Fejerskov O, Kidd E. Editor. Dental caries. The disease and its clinical management. 2nd edition. Blackwell Munksgard. 2008. 266-271.

[6] Parkar SM, thakkar, P, dan Shah K. Antimicrobial activity of four commercially available mouthwash against Streptococcus mutan an in vitro study. Univ Res J Dent. 2013. 3: 106-12

[7] Balagopal S, A. Radhika. Chlorhexidin : The Gold Standard Antiplaque Agent. Journal of Pharmaceutical sciences and Research. 2013. 5:12:270-274

[8] Amin M, Kazemi M, Rasaie N. In vitro comparison of the effects of garlic and chlorhexedine mouthwash on oral pathogens. Jundishapur J Microbiol. 2012. 5:2.

[9] Buknov N. Which is better, natural herbal or chemical medicines. 2009.. Diunduh dari http://enzinearticles.com/3873647.

[10] Fani M , Kohanteb J. Inhibitory activity of Aloe vera gel on some clinically isolated cariogenic and periodontopathic bacteria. Journal of Oral Science. 2012. 54:1: 15-21.

[11]Bassetti A, Sala S. The Great Aloe Book. $1^{\text {st }}$ edition. Zuccari. 2005. 46-56.

[12] Juneby H. Aloe barbadensia- a legendary medical plant. Pharmacognosy. Sweden. 2009. 212-234.

[13] Lawrence R, Tripathi P, Jayakumar E. Isolation, Purification and Evaluation of Antibacterial agents from Aloe vera. Brazilian Journal of Microbiology. 2009.40 : 906-915.

[14]Pratiwi R. Perbedaan daya hambat terhadap Streptococcus mutans dari beberapa pasta gigi yang 


\section{International Journal of Science and Research (IJSR) \\ ISSN (Online): 2319-7064}

Index Copernicus Value (2013): 6.14 | Impact Factor (2014): 5.611

mengandung herbal. Maj. Ked. Gigi (Dent J). 2005.38 : 2. 64-67

[15] Neilands J. Acid tolerance of Streptococcus mutans biofilms. Malmo University. 2007. 50-60

[16]Forsten SD, Bjorklund M, Ouwehand MC. Streptococcus mutans, Caries and Simulation Models. Nutrients. Finland. 2010. 2. 290-298

[17] Marsh PD, Nyvad B. The oral microflora and biofilms on teeth. Dalam Fejerskov O, Kidd E. Editor. Dental caries. The disease and its clinical management. 2nd edition. Blackwell Munksgard. 2008. 164-168.

[18] Barandozi FN. Antibacterial activities and antioxidant capacity of Aloe vera. Organic and Medicinal Chemistry Letters. 2013.3:5.

\section{Author Profile}

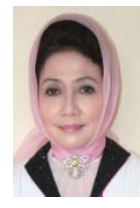

Yetty Herdiyati (Indonesia) received DDS from Universitas Padjadjaran in 1979. She continued to specialist program in Pedodontics in Universitas Padjadjaran and graduated in 1995. She finished her doctorate degree from Universitas Padjadjaran in 2007. She is a lecturer in Pedodontics Department of Universitas Padjadjaran. She is also a member of Indonesian Dentist Association and Indonesian Pediatric Dentist Association.

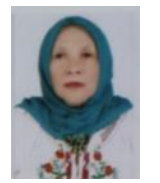

Mieke Hemiawati Satari (Indonesia) ) received DDS from Universitas Padjadjaran in 1979. She continued to post graduate programme in Masters of Health in 1990. She finished her doctorate degree from Universitas Padjadjaran in 2003. She is now a lecturer in Oral Biology Department of Faculty of Dentistry of Universitas Padjadjaran.

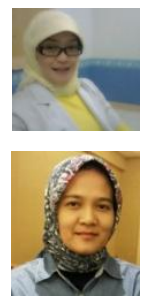

Ratna Indriyanti is a lecturer in Pedodontics Department of Faculty of Dentistry of Universitas Padjadjaran

Selly Patawulandari received DDS from Universitas Padjadjaran in 2002. She continued to specialist program in Pedodontics in Universitas Padjadjaran and graduated in 2015. 